\title{
Evaluation of patients hospitalized in a geriatrics clinic during normalization process of SARS CoV-2
}

\author{
SARS CoV-2 pandemisi normalleşme sürecinde geriatri kliniğinde yatan hastaların \\ değerlendirilmesi
}

Zehra Kosuva Öztürk

Sinem Sağlanmak Kabadayı (D) Sevnaz Şahin (D)

Selahattin Fehmi Akçiçek (D)

Ege University, Division of Geriatrics, Department of Internal Medicine, Izmir, Turkey

\begin{abstract}
Aim: The pandemic of Severe Acute Respiratory Syndrome-Coronavirus-2 was more severe and more fatal for elders and individuals who have chronic diseases. The treatment may be delayed due to the elders' "fear of infection" in hospitals. This study aimed to evaluate the data of older patients who were admitted to the Geriatrics clinic in the normalization period.

Materials and Methods: The data was retrieved between June-August 2020, retrospectively from the file database for older patients who were hospitalized in a geriatrics clinic of a university hospital.

Results: 23 patients were included in the study and their mean age was $81.4 \pm 7.4$ years. The most common symptoms at admission were changes in consciousness, weight loss, and malnutrition, respectively. The duration of symptoms was less than a month in $56.5 \%$ of patients, $1-3$ months in $17.4 \%$ of patients, and more than 3 months in $26.1 \%$ of patients. The most common indications were delirium, urinary tract infection, and acute renal failure, respectively $73.9 \%$ of patients applied from the outpatient clinics and $26.1 \%$ from the emergency clinic. The mean hospitalization duration was $24.2 \pm$ 17,2 days. $43.5 \%$ of patients had delirium and $21.7 \%$ had pressure ulcers during their hospitalization.

Conclusion: The hospitalization indications had variations, outpatient hospitalizations were higher, and the duration of hospitalization was longer during normalization process of SARS CoV-2. Approximately, half of the patients had symptoms for more than a month and it is an important point to be investigated. In addition, geriatric syndromes such as delirium and pressure ulcer increased in this process.
\end{abstract}

Keywords: Elderly, inpatient, COViD-19 pandemics.

\section{ÖZ}

Amaç: Yeni koronavirüse (SARS-CoV-2, Şiddetli Akut Solunum Yolu Sendromu Koronavirüsü 2) bağlı pandemi, kronik hastalığı olan bireylerde ve yaşlılarda daha şiddetli seyretmiş, daha sık ölümlere sebep olmuştur. Hastalık bulaşma korkusu, yaşılların sağlık sorunları yaşadıklarında almaları gereken bakım ve tedavinin gecikmesine sebep olabilmektedir. Bu çalışmada, normalleşme sürecinde geriatri kliniğine yatışı yapılan ileri yaş hastaların değerlendirilmesi amaçlanmıştır.

Yöntem: Haziran-Ağustos 2020 tarihlerinde Ege Üniversitesi Tıp Fakültesi Geriatri kliniğine yatışı yapılan $\geq 65$ yaş tüm hastaların verileri retrospektif olarak elektronik hasta dosya sisteminden elde edilmiştir. Çalışmaya sağlık bakanlığı ve etik kurul onayı alınması sonrasında başlanmıştır.

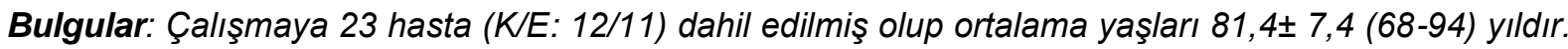
En sık başvuru semptomlarını hastaların \%34,7'sinde bilinç değişikliği, \%17,3'ünde kilo kaybı ve \%13'ünde beslenme bozukluğu oluşturmaktadır.

\footnotetext{
Corresponding author: Zehra Kosuva Öztürk

Ege University, Division of Geriatrics, Department of Internal

Medicine, Izmir, Turkey

E-mail: zehra88kosuva@hotmail.com
} 
Semptomlar, hastaların \%26,1'inde 3 aydan daha uzun süredir, \%17,4ünde 1-3 ay arasında, $\% 56,5$ 'inde ise bir aydan daha kısa süredir mevcuttur. En sık yatış endikasyonlarını hastaların \%26'sında deliryum, \%17,3'ünde idrar yolu enfeksiyonu, \%17,3'ünde akut böbrek yetmezliği oluşturmaktadır. Yatan hastaların \%73,9'u poliklinikten, \%26,1'i acilden başvurmuştur. Hastanede ortalama yatış süreleri 24,2 \pm 17,2 gündür. Hastane yatışları sırasında, hastaların \%43,5'inde deliryum, \%21,7'sinde ise bası yarası saptanmıştır.

Sonuç: Bu çalışma sonucunda SARS-CoV-2 pandemisi normalleşme sürecinde, yatış endikasyonlarının çeşitli olduğu, poliklinikten yatışların daha fazla olduğu ve yatış süresinin uzun olduğu saptanmıştır. Hastaların yaklaşık yarısında semptomların 1 aydan uzun süredir olduğu görülmüştür ve bu konu araştırıması gereken bir noktadır. Ayrıca, deliryum ve bası yarası gibi geriatrik sendromların bu süreçte arttığı görülmüştür.

Anahtar Sözcükler: Yaşlı, yatan hasta, COViD-19 pandemisi.

\section{INTRODUCTION}

The cases of viral pneumonia reported in city of Wuhan, China in December 2019 were subjected to sequence analyses, and the causative agent was named the 2019 novel coronavirus (2019nCoV) $(1,2)$. This novel coronavirus was officially named Severe Acute Respiratory Syndrome Coronavirus 2 (SARS-CoV-2), and the infection caused by this virus was named Coronavirus Disease 2019 (COVID-19) (3). After cases started to be reported worldwide in addition to China, the World Health Organization (WHO) declared the outbreak a pandemic on March 11, 2020.

At the end of December 2020, the number of cases reported worldwide exceeded 80 million, with over 1.8 million deaths attributed to SARSCoV-2 infection. In Turkey, according to the data as of the end of December, the number of people with confirmed COVID-19 was over 2 million, while deaths from SARS-CoV-2 infection numbered over 20,000 (4). The effects of the disease caused by the novel coronavirus (SARSCoV-2) are particularly severe in the elderly and in those with chronic diseases, resulting even in death. The highest risk group are those aged 85 or older. The estimated risk of mortality is $8 \%$ in the $70-79$ years age group, compared to $14 \%$ in those aged $\geq 80$ years (5).

After the risk of mortality associated with coronavirus in the elderly was identified, a curfew was imposed on those aged $\geq 65$ in our country (6). The dramatic change brought about by the social distancing measures brought significant challenges to the maintenance of the health and well-being of community-dwelling older adults, particularly those who were frail, very old or with multiple chronic conditions (7). Older adults are at a high risk of death from COVID-19, and this age group is also associated with high rates of morbidity and mortality due to the presence of other acute and chronic conditions. They adapt poorly to aggressive physical distancing and the resulting changes in health system structures. When health problems occur, fear of infection may delay the provision of necessary care and treatment in the elderly.

After the number of cases decreased and the necessary measures were taken, a normalization period was initiated, including the lifting of the curfew imposed on people aged $\geq 65$ on 03.06.2020 (8). We present here an evaluation of elderly patients who were admitted to a Geriatrics clinic in the normalization period, and who had been affected by the pandemic and the resulting isolation.

\section{MATERIALS AND METHODS}

With the reorganization of beds due to the pandemic, no patients could be admitted to the geriatrics clinic of Ege University Medical Faculty Hospital between March and May 2020. Upon a decline in the number of cases, the curfew was lifted, and a period of normalization was initiated in June 2020, when patients requiring hospitalization for reasons other than COVID-19 stated to be admitted again. This study included all patients aged $\geq 65$ years who were admitted to the inpatient ward of the Geriatrics Clinic of Ege University Medical Faculty Hospital between June and August 2020 (in the normalization period). The demographic data, presenting symptoms, duration of presenting symptoms, living alone or with family before admission, comorbidities, indications for hospitalization and length of hospital stay of all patients were retrieved from the electronic medical record system. Data on the frequency of pressure sores and delirium among the geriatric syndromes 
detected at admission were retrieved from the patients' medical records. In addition, the presence of fever at admission was examined, and the rates and results of any COVID-19 tests performed were noted on the questionnaire forms. This retrospective study was approved by the Ministry of Health (Form No: 2020-0831T21_23_39) and by the Ethics Committee of the Ege University Faculty of Medicine (Date: 11.25.2020, No: 20-11.1T / 40).

All study data were assessed using IBM SPSS Statistics (Version 21.0. Armonk, NY: IBM Corp.). For the quantitative variables, normally distributed variables were summarized using mean and standard deviation, while median, maximum and minimum values were used to express non-normally distributed variables. For qualitative variables, a frequency analysis was carried out as a descriptive statistical method.

\section{RESULTS}

The study included 23 patients admitted to the inpatient ward of the Geriatrics Clinic of Ege University Medical Faculty Hospital between June and August 2020. Of these patients, 12 $(52.1 \%)$ were female and $11(47.8 \%)$ were male. The mean age of the overall sample was $81.4 \pm 7.4(68-94)$ years, 83.3 $\pm 7.03(72-94)$ years for female patients and $79.3 \pm 7.6(68-89)$ years for male patients. Only two $(8.7 \%)$ of the patients were living alone prior to admission to hospital.

Table-1. Common presenting symptoms and indications for hospitalization.

\section{All patients}

$n,(\%)$

\section{Symptom}

Change in consciousness

Weight loss

4 (17.3)

Malnutrition

Fever

Falls

Skin eruption

Shortness of breath

Skin ulcer

Abdomen distension

Rectal bleeding

\section{Hospitalization indication}

Delirium

Urinary tract infection

Acute renal failure

Malignancy examination

Aspiration pneumonia

PEG tube placement

Decompensated heart failure

Bullous pemphigoid

Gastroenteritis

Wound infection

Acid etiology

GIS bleeding

PEG, Percutaneous Endoscopic Gastrostomy; GIS, Gastrointestinal System. 
Table-2. Chronic diseases of study patients.

\begin{tabular}{ll}
\hline Chronic diseases & All patients $\mathbf{n},(\%)$ \\
\hline Hypertension & $19(82.6)$ \\
Heart failure & $13(56.5)$ \\
Dementia & $12(52.2)$ \\
Diabetes mellitus & $12(52.2)$ \\
Chronic renal failure & $12(52.2)$ \\
Coronary artery disease & $8(34.7)$ \\
Atrial fibrillation & $7(30.4)$ \\
Malignancy & $7(30.4)$ \\
Cerebrovascular accident & $5(21.7)$ \\
\hline
\end{tabular}

When the presenting symptoms of the 23 study patients were examined, the most common symptoms were found to be altered states of consciousness, followed by weight loss and malnutrition. The common presenting symptoms are provided in detail in Table-1. Some of the patients presented with more than one symptom: two patients presented with an altered state of consciousness accompanied by urinary tract symptoms; one patient with malnutrition and weight loss, one patient with an altered state of consciousness, fever and cough; and one patient with rectal bleeding, accompanied by weight loss. An analysis of the time from the onset of symptoms to hospital admission revealed that six $(26.1 \%)$ of the patients had complaints for more than 3 months, four (17.4\%) had complaints for $1-3$ months and $13(56.5 \%)$ for less than one month.

The most common indications for hospitalization were delirium, urinary tract infection and acute renal failure, in a decreasing order of frequency (Table-1). The indications for hospitalization are presented in detail in Table-1. Some patients had multiple indications for hospitalization: three patients were admitted due to delirium and urinary tract infections; one due to delirium and acute renal failure; and one due to aspiration pneumonia and indications necessitating an anemia examination. Of the sample, 17 (73.9\%) of the patients were admitted after presenting to the outpatient clinic and six $(26.1 \%)$ to the emergency department.

The most common chronic diseases among the patients under follow-up were hypertension, heart failure, dementia, and diabetes mellitus, in decreasing order of frequency. Comorbid chronic diseases are presented in detail in Table-2.

The mean length of hospital stay of the study patients was $24.2 \pm 17.2$ days. At the time of admission, delirium was identified in 10 (43.5\%) patients and pressure sores in five (21.7\%) patients, while $11(47.8 \%)$ of the patients had elevated body temperatures at admission. 19 of the patients $(82.6 \%)$ underwent at least one COVID-19 PCR test was performed, and all tests were negative. Of the total, three $(13 \%)$ patients died during their hospital stay.

\section{DISCUSSION}

The present study examined elderly patients who were hospitalized in the period of normalization under the COVID-19 pandemic, and found the indications for hospitalization to be diverse, hospitalization to be more common following outpatient visits and the length of stay to be prolonged. Approximately half of the patients had experienced the presenting symptoms for more than one month. There was also an increase in geriatric syndromes such as delirium and pressure sores in this period.

The COVID-19 pandemic has led to a unique psychological and socioeconomic situation as a result of its individual, social and global effects. Social distancing, quarantine, travel restrictions, school and workplace closures, and cancellations of sports and art activities have led to a pause in normal life (9). During the COVID-19 pandemic, the medical control visits of non-emergency patients have been cancelled, leading to necessary treatment changes not being made, and resulting in the poor control and management of chronic diseases (10-12). Incompliance with drug therapies in this period has been observed to result in severe acute and chronic complications in the elderly with chronic diseases (9). Several studies have reported pressure sores among inpatients in frequencies ranging from $5.5 \%$ to $17.5 \%$, while the frequency was $21.7 \%$ in the present study (13-15). The prevalence of delirium among inpatients has 
been reported in a range of $10-30 \%$ in various studies, while the prevalence was $43.5 \%$ in the present study (16).

In previous studies, the mean length of hospital stay of the elderly patients was 5.2 days, with prolonged hospitalization described as a stay in hospital for more than 13 days (17-19). In the present study, the mean length of hospital stay was $24.2 \pm 17.2$ days. The elderly patients with chronic diseases in the present study were admitted to our clinic with various indications. It was believed that the hospital stay was prolonged because hospital admissions were due to complications and accompanying geriatric syndromes such as pressure sores and delirium were common in patients. Considering the increasing prevalence of chronic conditions with age and the occurrence of chronic conditions mostly in the elderly, it is believed that the progression of diseases and the development of complications may affect individual and social well-being by placing greater burdens on both the patients and the healthcare system (20).

The increased allocation of healthcare resources to COVID-19, the reduction in the number of procedures offered at polyclinics, and the nonreferral or delayed referral of patients to healthcare facilities due to a fear of infection are likely to prevent early interventions in diseases, to decrease hospital admissions for serious nonCOVID-19 diseases, to cause inpatients to present with prolonged symptoms, and to make diseases become more complicated (21). The present study found that half of the patients presented to the hospital and were admitted to the ward with complaints that had lasted for more than one month. Similar problems in healthcare systems and services have been reported during previous outbreaks. A study in Taiwan during the SARS outbreak reported that outpatient treatments decreased by $23.9 \%$, inpatient treatments by $35.2 \%$, and referrals for dental health by $16.7 \%(22)$. In another study involving 79 patients receiving chemotherapy at a hospital in Taiwan during the SARS outbreak, approximately two-thirds of patients reported being concerned about going to the hospital due to their fear of infection, and $2.7 \%$ delay in planned chemotherapies was recorded (23). A study in Sierra Leone, in turn, reported that hospital admissions in the country decreased by $7 \%-32 \%$ in various regions during the Ebola outbreak (24).

The experience gained during previous outbreaks of other agents of the same coronavirus family has shown that the harmful effects of such outbreaks are not just limited to acute complications (25). The potential long-term complications of COVID-19 reported in previous studies suggest that the disease may threaten the functional competence of individuals in the future (26). Self-isolation can lead to lack of exercise, and thus to frailty and falls, resulting in disability, making it important to conduct research on this subject.

The limitations of this study included the small sample size and the short duration of the study, which can be attributed to the decrease in both outpatient visits and referrals to hospitals for various reasons in the normalization period under the COVID-19 pandemic. A second wave in the COVID-19 pandemic brought an end to the period of normalization, preventing the duration of the study being extended further

\section{CONCLUSION}

While senior adults are at a greater risk of death from COVID-19 than young adults, medical care for non-COVID-19 conditions should not be neglected. It should be noted that physical distancing and social isolation can cause severe damage not only to mental health, but also to physical health and mental functioning. During the pandemic, it is also important to pay attention to the challenges faced by frail older adults resulting from physical distancing, and to directly address such challenges.

This study was presented as an oral presentation at the International Symposium of World Shaking Pandemic SARS-CoV-2 and Elderly Health, held online on September 29-30, 2020.

\section{Conflict of interest}

No potential conflict of interest was reported by the authors.

\section{References}

1. Huang C, Wang Y, Li X, et al. Clinical features of patients infected with 2019 novel coronavirus in Wuhan, China. Lancet (London, England) 2020; 395 (10223): 497-506.

2. Zhu N, Zhang D, Wang W, et al. A novel coronavirus from patients with pneumonia in China, 2019. N Engl J Med 2020; 382 (8): 727-33. 
3. Gorbalenya AE, Baker SC, Baric R, et al. Severe acute respiratory syndrome-related coronavirus: The species and its viruses-a statement of the Coronavirus Study Group (2020). Nature Microbiology doi: 10.1038/s41564-020-0695-z

4. covid19.saglik.gov.tr (homepage on the Internet) General coronavirus picture (güncellenme tarihi: 26.01.2021, alıntılama tarihi: 27.01.2021) Available from: https://covid19.saglik.gov.tr/

5. Novel CPERE. The epidemiological characteristics of an outbreak of 2019 novel coronavirus diseases (COVID-19) in China. Zhonghua liu xing bing xue za zhi 2020; 41 (2): 145-51.

6. Demirbilek Y, Pehlivantürk G, Özgüler ZÖ, Meşe E.A. COVID-19 outbreak control, example of ministry of health of Turkey. Turkish journal of medical sciences 2020; 50: 489-94.

7. Steinman MA, Perry L, Perissinotto CM. Meeting the care needs of older adults isolated at home during the COVID-19 pandemic. JAMA internal medicine 2020; 180 (6): 819-20.

8. tr.wikipedia.org (homepage on the Internet) Covid19 pandemic timeline in Turkey (updated 17.11.2020; cited 27.01.2020). Available from: https://tr.wikipedia.org/wiki/

9. Çavdar S, Şahin S. SARS-CoV-2 pandemisinin sağlıklı yaşlanma sürecine etkileri. Şahin S, Akçiçek SF, editörler. SARS-CoV-2 Pandemisi ve Yaşılık. 1. Baskı. Ankara: Türkiye Klinikleri; 2020: 77-82.

10. Palmer K, Monaco A, Kivipelto M, et al. The potential longterm impact of the CoVID-19 outbreak on patients with non-communicable diseases in Europe: consequences for healthy ageing. Aging Clin Exp Res 2020; 32 (7): 1189-94.

11. Lim MA, Huang I, Yonas E, Vania R, Pranata R. A wave of non-communicable diseases following the CoVID19 pandemic. Diabetes Metab Syndr 2020; 14 (5): 979-80.

12. Kretchy IA, Asiedu-Danso M, Kretchy JP. Medication management and adherence during the CoVID-19 pandemic: Perspectives and experiences from low-and middle-income. Research in Social and Administrative Pharmacy 2020; 17 (1): 2023-6.

13. Hug $E$, Ünalan $H$, Karamehmetoğlu $S$, Tüzün $S$, Gürgöze $M$, Tüzün $F$. Bir eğitim hastanesinde bası yarası prevelansı ve bası yarası gelişiminde etkili risk faktörleri. Turkish Journal of Physical Medicine and Rehabilitation 2001; 47 (6): 3-11.

14. Inan DG, Öztunç G. Pressure ulcer prevalence in Turkey: a sample from a university hospital. Journal of Wound Ostomy \& Continence Nursing 2012; 39 (4): 409-13.

15. Uzun $\mathrm{O}$, Tan M. A prospective, descriptive pressure ulcer risk factor and prevalence study at a university hospital in Turkey. Ostomy/Wound Manage 2007; 53 (2): 44-56.

16. Siddiqi N, House AO, Holmes JD. Occurrence and outcome of delirium in medical in-patients: a systematic literature review. Age Ageing 2006; 35 (4): 350-64.

17. Freeman WJ, Weiss AJ, Heslin KC. Overview of US hospital stays in 2016: Variation by geographic region. Healthcare Cost and Utilization Project 2018 (cited 6 Feb 2021). Available from: https://www.hcupus.ahrq.gov/reports/statbriefs/sb246-Geographic-Variation-Hospital-Stays.jsp

18. Launay CP, Kabeshova A, Lanoé A, Chabot J, Levinoff, EJ, Beauchet O. Age effect on the prediction of risk of prolonged length hospital stay in older patients visiting the emergency department: results from a large prospective geriatric cohort study. BMC geriatrics 2018; 18 (1): 1-6.

19. Launay CP, de Decker L, Kabeshova A, Annweiler C, Beauchet O. Screening for older emergency department inpatients at risk of prolonged hospital stay: the brief geriatric assessment tool. PLoS One 2019; 9 (10). e110135 doi: 10.1371/journal.pone.0110135

20. Michel JP, Ecarnot F. Integrating functional ageing into daily clinical practice. Journal of frailty, sarcopenia and falls 2019; 4 (2): 305.

21. Ekici E. Care Management of Elderly People During Covid 19 Pandemic. Haliç University. Journal of health sciences 2020; 3 (3): 145-52.

22. Chang HJ, Huang N, Lee CH, Hsu YJ, Hsieh CJ, Chou YJ. The impact of the SARS epidemic on the utilization of medical services: SARS and the fear of SARS. American journal of public health 2004; 94 (4): 562-4.

23. Chen $\mathrm{T}$, Lai $\mathrm{K}$, Chang $\mathrm{H}$. Impact of a severe acute respiratory syndrome outbreak in the emergency department: an experience in Taiwan. Emergency medicine journal 2004; 21 (6): 660-2.

24. Brolin Ribacke KJ, van Duinen AJ, Nordenstedt H, et al. The Impact of the West Africa Ebola Outbreak on Obstetric Health Care in Sierra Leone. PLoS One 2016; 11 (2). e0150080 doi: 10.1371/journal.pone. 0150080

25. Dasgupta A, Kalhan A, Kalra S. Long term complications and rehabilitation of CoVID-19 patients. J Pak Med Assoc 2020; 70 (Suppl 3) (5): 131-5.

26. Li J. Rehabilitation management of patients with COVID-19: lessons learned from the first experience in China. European journal of physical and rehabilitation medicine 2020; 56 (3): 335-8. 